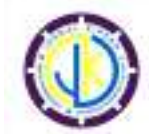

e-ISSN: $2580-6947$

p-ISSN: 2354-7278

http://ojs.umrah.ac.id/index.php/kiprah/index

\title{
BAHASA DAN KEKUASAAN POLITIK OPOSAN DI INDONESIA: ANALISIS WACANA KRITIS
}

\section{Eko Kuntarto}

Universitas Jambi, Kota Jambi, Jambi, Indonesia

\begin{abstract}
Abstrak
Penelitian ini bertujuan untuk mendeskripsikan relasi-relasi kekuatan tak-tampak (hidden power) dengan proses ideologis yang muncul dalam wacana lisan atau tulisan. Fokus penelitian ini adalah pada gaya bahasa yang dipilih oleh para politikus oposan. Penelitian ini menggunakan metode Analisis Wacana Kritis model Fairclough. Korpus data diperoleh secara acak dari 4 media sosial daring nasional yang tersaji di internet. Data diambil selama 3 bulan. Dari hasil penelitian diketahui, ada 4 kelompok dan 36 jenis gaya bahasa yang digunakan oleh para politikus dalam bertutur di media sosial daring, yaitu ironi ( 21 jenis), perbandingan ( 7 jenis), pertentangan (4 jenis), dan penegasan (4 jenis). Hasil juga diketahui 4 fenomena gaya bahasa politikus oposan di Indonesia, yaitu, 1) kecenderungan untuk menggunakan diksi yang bermakna sarkastik, melecehkan, membuli, menyudutkan, menyatakan yang sebaliknya, dan apriori; 2) kebenaran realistis dikalahkan oleh kebenaran praktis, 3) hilangnya sikap empati, penghargaan, dan kesantunan; 4) bahasa digunakan sebagai alat politik, dan bukan sebagai alat interaksi sebagaimana dimaksud dalam teori kesantunan berbahasa.
\end{abstract}

Kata-kata kunci: bahasa, kekuasaan, politik, media sosial daring

\section{Pendahuluan}

Akhir-akhir ini media sosial daring di Indonesia diramaikan dengan munculnya jenis wacana baru yang mengindikasikan spesifikasi khas ragam bahasa politikus oposan. Keberadaan wacana khas politik tersebut memunculkan sikap skeptis, baik dari kalangan praktisi bahasa maupun masyarakat umum. Meskipun fenomena tersebut bersifat situasional dan temporal karena hanya terjadi pada masa pemilihan umum, namun dampaknya cukup luas. Saat ini bahasa tidak hanya sebagai alat komunikasi dan interaksi semata. Bahasa telah menjadi media perantara dalam pelaksanaan kuasa melalui ideologi. Bahkan bahasa juga menyumbang proses dominasi terhadap orang lain oleh pihak lain. Bahasa telah menjadi komoditas politik (Fairclough, 2001).

Menurut Anderson, penggunaan bahasa untuk kepentingan politik bukan suatu hal yang baru di Indonesia, bahkan di dunia (Nasution, 2007). Penggunaan bahasa sebagai alat politik di Indonesia berawal dari kenyataan yang tidak

*Penulis Korepondensi

Email Address : ekokuntarto28@unja.ac.id terelakkan bahwa ia lahir dari tiga bahasa yang berbeda dan dua tradisi budaya yang berbeda pula. Tiga bahasa tersebut adalah Belanda, Jawa, dan Melayu revolusioner. Adapun tradisinya adalah budaya Belanda, Barat, dan Jawa. Yang menarik, tokoh-tokoh politik Indonesia menggunakan bahasa bukan saja untuk menyatakan ide, pendapat atau pikirannya, tetapi juga menyampaikan pikiran yang mengandung kepentingan-kepentingan kekuasaan yang harus dipertahankan, apapun caranya. Dalam pelaksanaanya, setiap rezim rezim pemerintahan dan kelompok politik menggunakan repertoar yang berbeda-beda. Karakter bahasa di antara mereka juga berbeda-beda, bergantung pada konteks politik yang berkembang saat itu.

Sekaitan dengan pendapat Anderson (Nasution, 2007), pada era perpolitikan masa lalu (orde lama dan orde baru), repertoar Bahasa Indonesia dibanjiri dengan penggunaan akronim dan eufemisme yang berlebihan. (Kuntarto E., 2017). Pada era reformasi dewasa ini, penggunaan bahasa oleh kelompok politik 
JURNAL KIPRAH, Desember 2018; V1(2): 37-47

e-ISSN: 2580-6947

p-ISSN: 2354-7278

oposan lebih memprihatinkan lagi. Repertoar bahasa politik bukan hanya sebatas pada penggunaan diksi yang menyimpang, melainkan lebih dalam lagi yakni pengubahan hakikat bahasa yang semula berfungsi untuk berinteraksi dan menjalin hubungan baik menjadi reportoar bahasa yang menyebarkan kebohongan, kebencian, anarkhisme, sikap antisosial, pertikaian, bahkan peperangan. Bahasa telah digunakan sebagai "senjata" untuk memusuhi lawan dan mengajak masyarakat untuk saling berperang.

Berdasarkan latar belakang tersebut maka penelitian tentang Bahasa dan Kekuasaan Politik Di Indonesia: Analisis Wacana Kritis perlu dilakukan. Melalui penelitian ini diharapkan dapat diketahui kaitan antara bahasa dan politik, bahasa dan kekuasaan, praktik penggunaan bahasa dalam bertutur dengan latar belakang ideologis dan filosofis, serta ragam bahasa khas politisi oposan.

\section{Kajian Teori}

Fenomena penggunaan bahasa oleh Kelompok Politik Di Indonesia, tidak sematamata berkaitan dengan aspek-aspek penggunaan bahasa (language use) namun berkaitan juga dengan perilaku sosial (social attitude), yang banyak diungkap dalam telaah psikologi behaviorisme (Redinger, 2010). Paradigma behaviorisme dalam ilmu politik sering menjadi landasan teori dalam telaah kasus pemilihan umum di berbagai negara. Hal itu karena dalam studi politik, perilaku pemilih (voting behaviour) menjadi salah satu topik telaah yang menarik. Sistem pemilihan umum terus berkembang, tema kampanye tidak pernah sama, dan karakter pemilihnya juga selalu unik. Perilaku bahasa menjadi pusat telaah teori bahasa behavioristik (Kuntarto E., 2017). Data penggunaan bahasa dapat diamati dan diukur dalam kaitannya dengan stimulus dan respon yang dapat menimbulkan dampak dalam bentuk perilaku tertentu (Kuntarto E., 2017), (Dafrizal, 2016).

Dalam hubungannya dengan penggunaan gaya bahasa dalam bertutur di media sosial, teori behavioristik tampaknya sesuai untuk mengupas

landasan filosofis penggunanya. Respon berupa perilaku untuk mendukung kelompok tertentu, dan sebaliknya menolak atau tidak mendukung kelompok tertentu menjadi tujuan utama para potisi dalam bertutur di media sosial untuk kepentingan politiknya. Hal ini menarik untuk dikaji karena adanya ketidakbiasaan (anomali) dalam menggunakan bahasa sebagai alat interaksi sosial yang sering dibahas dalam telaah pragmatik dan kesantunan berbahasa, sebagaimana dikemukakan, antara lain, oleh Brown \& Levinson (Levinson, 1983), (Brown \& Levinson, 1987). Dalam teori interaksi, bahasa digunakan untuk menjaga hubungan baik antarpenggunanya (Kuntarto E., 2018). Jadi, jika bahasa kemudian menjadi alat untuk bermusuhan, maka tentu ada yang keliru dalam pemanfaatan bahasa sebagai alat interaksi (Brown \& Levinson, 1987).

Selanjutnya, menurut paham analisis wacana kritis (Critical Discourse Analysis), teks bukanlah sesuatu yang bebas nilai dan menggambarkan realitas sebagaimana adanya. Kecenderungan pribadi dari sang produsen teks dan struktur sosial yang melingkupi sang produsen teks ikut mewarnai isi teks. Bahasa tidak netral melainkan membawa pesan ideologi tertentu yang dipengaruhi oleh sang pembuat teks. Analisis Wacana Kritis memahami wacana tidak semata-mata sebagai suatu studi bahasa, tetapi juga menghubungkannya dengan konteks. Konteks yang dimaksud adalah konteks praktik kekuasaan yang bertujuan untuk memarginalkan individu atau kelompok tertentu melalui penggunaan kekuasaan dalam memproduksi teks atau wacana (Fairclough, 2001).

Dalam hubungannya dengan kelompok, untuk membangun stigma negatif pada diri lawan politik, kelompok oposan membentuk struktur skemata tertentu dengan kata-kata dan gaya berbicara. Struktur skemata tersebut dibangun melalui berbagai cara, termasuk membuat stimulus negatif tentang lawan politiknya melalui informasi hoaks.

Dalam politik, semua kegiatan komunikasi berkaitan dengan upaya untuk meraih simpati, memperluas jaringan, dan memperkuat 
hegemoni. Pesan politik dipertukarkan melalui simbol-simbol verbal dan nonverbal. Retorika angka (tokoh masyarakat, politisi, anggota legislatif, eksekutif, presiden, etc.), yang mengungkapkan pernyataan, wawancara, pidato, siaran pers pada dasarnya memiliki niat politik. Komunikasi dilakukan dengan menggunakan bahasa sebagai media, termasuk media daring. Dalam pandangan analisis wacana, setiap ucapan atau tulisan memiliki arti tertentu dan tujuan. Oleh karena itu, bahasa merupakan representasi pribadi yang dapat mewakili seseorang pada kapasitas tertentu; ulama, cendekiawan, politikus, birokrat, dan sebagainya (Kuntarto, 1999). Gayut dengan hal itu, perlu dirujuk temuan Pentzold, Sommer, Meier, \& Fraas dalam studinya tentang kasus model peran wacana multimodal, dimana pesan dan gambar tertulis, siaran, komentar, dan visual yang menyebar melalui media sosial, dapat membingkai isu-isu dan membawa publik dalam pertentangan tiada akhir (Pentzold, Sommer, Meier, \& Fraas, 2016). Bagi bangsa Indonesia yang majemuk, isu-isu politik semacam itu dapat menjadi pendorong disintegrasi.

Telaah tentang penggunaan gaya bahasa oleh elit politik oposan berhubungan erat dengan pemaknaan tuturan. Pemaknaan maksud tuturan harus melibatkan banyak aspek, antara lain konteks tuturan. Akan tetapi, sebagai sebuah studi komunikasi, fokus relevan yang ditinjau adalah tujuan dan maksud tersembunyi dari sebuah tuturan, bukan struktur gramatikal atau deskripsi pembangunan pernyataan. Dalam analisis wacana kritis fokusnya bukan apa yang dinyatakan, tetapi bagaimana pesan disampaikan dan mengapa ia memilih cara itu (Weiss, G and Wodak, 2006), (de Beaugrande, 2006). Oleh karena itu, telaah tentang gaya bahasa dalam wacana politik tidak cukup menggunaan pendekatan linguistik, melainkan juga pendekatan pragmatik (Levinson, 1983). Dengan pendekatan pragmatik, maka tuturan atau kalimat akan dikaji dari maksud dan tujuannya (Kuntarto, 1999).

Dalam kaitan dengan analisis wacana politik, tiga pendekatan yang didasarkan psikologi konstruksionisme sosial diajukan untuk dibahas secara khusus di sini. Ketiga pendekatan tersebut adalah Pendekatan Kritis, Pendekatan Kultural dan Historis, serta Pendekatan Hubungan yang dibagi dalam dua kategori, yakni Hubungan antara Pengetahuan dan Proses Sosial dan hubungan antara Pengetahuan dan Tindakan Sosial (Gergen, 2012).

Faiclough berpendapat bahwa analisis wacana kritis adalah bagaimana bahasa menyebabkan kelompok sosial yang ada bertarung dan mengajukan ideologinya masingmasing. Analisis Wacana melihat pemakaian bahasa tutur dan tulisan sebagai praktik sosial. Praktik sosial dalam analisis wacana dipandang menyebabkan hubungan yang saling berkaitan antara peristiwa yang bersifat melepaskan diri dari dari sebuah realitas, dan struktur sosial (Fairclough, 1995). Konsep yang dibentuk oleh Fairclough menitikberatkan pada tiga level. Pertama, setiap teks secara bersamaan memiliki tiga fungsi, yaitu representasi, relasi, dan identitas. Kedua, praktik wacana meliputi caracara para pekerja media memproduksi teks. Hal ini berkaitan dengan wartawan itu sendiri selaku pribadi; sifat jaringan kerja wartawan dengan sesama pekerja media lainnya, pola kerja media sebagai institusi, seperti cara meliput berita, menulis berita, sampai menjadi berita di dalam media. Ketiga, praktik sosial-budaya menganalisis tiga hal yaitu ekonomi, politik (khususnya berkaitan dengan isu-isu kekuasaan dan ideologi) dan budaya (khususnya berkaitan dengan nilai dan identitas) yang juga mempengaruhi institusi media dan wacananya. Pembahasan praktik sosial budaya meliputi tiga level, yaitu: level situasional, institusional, dan sosial. Level situasional berkaitan dengan produksi dan konteks situasinya. Level institusional berkaitan dengan pengaruh institusi secara internal maupun eksternal. Level sosial berkaitan dengan situasi yang lebih makro, seperti sistem politik, sistem ekonomi, dan sistem budaya masyarakat secara keseluruhan (Fairclough, 1995).

Analisis wacana kritis model Norman Fairclough bertumpu pada pandangan tentang bagaimana bahasa digunakan untuk melihat terjadinya ketimpangan kekuasaan dalam 
JURNAL KIPRAH, Desember 2018; V1(2): 37-47

e-ISSN: 2580-6947

p-ISSN: 2354-7278

masyarakat. Menurut Fairclough, analisis wacana kritis menyelidiki bagaimana penggunaan bahasa kelompok sosial yang ada saling bertarung dan mengajukan versinya masing-masing, yang betumpu pada lima prinsip, yakni: 1) Prinsip Tindakan, 2) Prinsip Konteks, 3) Prinsip Histori, 4) Prinsip Kekuasaan, dan 5) Prinsip Ideologi. Model Fairclough (Fairclough, 2001) membagi analisis wacana kritis ke dalam tiga dimensi, yakni: 1) dimensi mikrostruktural, 2) dimensi mesostruktural, dan 3) dimensi sosial-budaya

\section{Metode Penelitian}

Dalam penelitian ini digunakan metode Analisis Wacana Kritis model Fairclough (Fairclough, 2001). Searah dengan model tersebut, maka dasar analisisnya mengacu pada teori pragmatik dan analisis wacana Halliday (Kuntarto E., 2017), yang menelaah struktur dan fungsi bahasa ke dalam struktur tata bahasa. Variabel yang diteliti berkaitan dengan kelompok politik, yang dalam peta perpolitikan di Indonesia terdapat pemisahan yang jelas. Ada dua kelompok politik, yaitu Kelompok Pendukung Pemerintah (KPP) dan Kelompok (KEPO). KPP adalah kelompok pendukung pemerintah yang sedang berkuasa. KEPO adalah kelompok yang tidak mendukung pemerintah yang sedang berkuasa (oposan). KPP terdiri dari 9 (sembilan) partai politik, yakni PDIP, PKB, Golkar, Perindo, NasDem, Hanura, PKPI, PSI, dan PPP. Sementara KEPO diisi oleh PKS, PAN, Demokrat, dan Gerindra. KPP menamakan dirinya Koalisi Indonesia Kerja (KIK). Adapun kelompok KEPO menamakan dirinya Koalisi

Indonesia Adil Makmur (KIAM). Penelitian ini mencakup pengambilan data dalam ranah kontestasi pilpres, pileg, dan pilkada sekaligus.

Data diambil dalam masa pra-kampanye, yakni Agustus-Oktober 2018. Data diperoleh dari empat sumber data, yakni detik.com, kompas.com, liputan6.com, dan tribunnews.com. Data yang terkumpul berjumlah 48 dokumen berita yang diambil dari 12 kali pengambilan pada 4 sumber data. Masing-masing diambil 1 berita yang paling populer dan terbaru.

Analisis data dilakukan dengan membuat interpretasi terhadap teks melalui kombinasi antara teks dan "pemakna" teks. Pemaknaan terhadap teks menggunakan berbagai sumbersumber sehingga dapat menghasilkan suatu interpretasi yang paling mendekati kebenaran

\section{Hasil dan Pembahasan}

Dari keempat sumber data tersebut terkumpul 48 teks, baik dalam bentuk tuturan langsung maupun tuturan tidak langsung. Tuturan tersebut disampaikan oleh elit politik partai, yakni PKS, PAN, Demokrat, dan Gerindra. Elit politik tersebut adalah pimpinan partai dalam berbagai tingkatan, baik pimpinan daerah (provinsi, kabupaten/kota) maupun pimpinan pusat, serta partisan (pendukung) partai-partai politik, yang belum jelas partainya dan bukan pimpinan partai.

Berdasarkan tingkat keseringannya membuat pernyataan atau berita di media sosial (minimal 1 kali dalam sepekan), tercatat beberapa elit politik yang dapat dijadikan sumber data. Namanama mereka adalah sebagai berikut.

Tabel 1. Daftar Pembuat Berita

\begin{tabular}{|c|c|c|c|c|c|c|c|c|}
\hline No & Initial & Text & Subject Code & No & Initial & Text & Subject Code & Data Source \\
\hline 1. & $\mathrm{AR}$ & 8 & P-01 & 8. & NW & 2 & P-06 & \multirow{7}{*}{$\begin{array}{ll}\text { - } & \text { kompas.com } \\
\text { - } & \text { detik.com } \\
\text { - } & \text { tribunnews.c } \\
\text { om } \\
\text { - liputan6.com }\end{array}$} \\
\hline 2. & $\mathrm{FH}$ & 7 & P-02 & 9. & MAS & 2 & P-07 & \\
\hline 3. & $\mathrm{FZ}$ & 7 & $\mathrm{P}-03$ & 10. & SBY & 2 & $\mathrm{P}-08$ & \\
\hline 4. & RS & 5 & S-01 & 11. & HR & 1 & P-09 & \\
\hline 5. & SU & 4 & P-04 & 12. & RR & 1 & S-03 & \\
\hline 6. & HRS & 4 & S-02 & 13. & $\overline{\mathrm{DS}}$ & 1 & P-10 & \\
\hline 7. & PS & 3 & P-05 & 14. & AHY & 1 & $\mathrm{P}-11$ & \\
\hline
\end{tabular}


Jika dilihat dari faktor pendukung terjadinya wacana, maka ke 48 teks tersebut dapat dipilah menjadi beberapa kategori, yakni aspek konteks, latar, dan sosial-budaya. Aspek konteks mencakup, (1) pernyataan, (2) pertanyaan, (3) tanggapan atas pernyataan, (4) tanggapan atas tanggapan, (5) memberitakan, (6) mengulas, (7) memancing pernyataan, dan (8) ide atau gagasan. Aspek latar belakang terdiri atas, (1) mempertahankan kekuasaan, (2) melemahkan kekuasaan, (3) mengungkapkan sejarah, (4) menunjukkan identitas idiologis, menunjukkan identitas kekuasaan, dan (6) menunjukkan dominasi atau hegemoni. Aspek sosial-budaya mencakup, (1) mengkritik, (2) menyerang, (3) melemahkan, (4) mengejek atau merundung (mengganggu, mengusik, menyusahkan, dll), (4) menyalahkan, (5) mengungkapan yang sebaliknya, (6) melawan, (8) mengecilkan/ meremehkan, dan (9) meninggikan diri/ mengangkat diri.

Tabel 2. Analisis Wacana Berdasarkan Dimensi Mikrostruktural dan Makrostruktural

\begin{tabular}{|c|c|c|c|}
\hline \multicolumn{2}{|c|}{ Faktor Pendorong } & Kode Wacana & Jumlah \\
\hline \multirow[t]{8}{*}{ Konteks } & (1) pernyataan & $\begin{array}{l}\text { W01, W10, W11, W12, } \\
\text { W20, W21, W22, W28, W30,W31, W32, } \\
\text { W34, W38, W40, W41, W46. }\end{array}$ & 16 \\
\hline & (2) pertanyaan & W02, W03. & 2 \\
\hline & (3) tanggapan atas pernyataan & $\begin{array}{l}\text { W04, W15, W23, W24 } \\
\text { W35, W36, W43, W44, W42 }\end{array}$ & 9 \\
\hline & (4) tanggapan atas tanggapan & $\begin{array}{l}\text { W05, W06, W16, W17 } \\
\text { W25, W37, W45 }\end{array}$ & 7 \\
\hline & (5) berita & W07, W08, W13, W14, W18, W26, W27. & 7 \\
\hline & (6) ulasan & W19 & 1 \\
\hline & (7) memancing pernyataan & W09, W19, W29, W39, W47. & 5 \\
\hline & (8) ide atau gagasan & W20. & 1 \\
\hline \multirow{6}{*}{$\begin{array}{l}\text { Latar } \\
\text { Belakang }\end{array}$} & (1) mempertahankan kekuasaan & W01, W10, W11, W12, & 4 \\
\hline & (2) melemahkan kekuasaan & W20, W30,W31, W40, W41, & 5 \\
\hline & (3) mengungkapkan sejarah & W20 & 1 \\
\hline & $\begin{array}{l}\text { (4) menunjukkan identitas } \\
\text { idiologis }\end{array}$ & W04, W15, W23, W36, & 4 \\
\hline & $\begin{array}{l}\text { (5) menunjukkan identitas } \\
\text { kekuasaan }\end{array}$ & $\begin{array}{l}\text { W04, W15, W24, W25, W26 W30,W31, } \\
\text { W40, W43, W44, W43, W44 }\end{array}$ & 12 \\
\hline & $\begin{array}{l}\text { (6) menunjukkan } \\
\text { dominasi/hegemoni. }\end{array}$ & W27, W28, W29 & 4 \\
\hline \multirow[t]{6}{*}{$\begin{array}{l}\text { Sosial- } \\
\text { Budaya }\end{array}$} & (1) mengkritik & $\begin{array}{l}\text { W01, W12, W20, W31, } \\
\text { W40, W41, W42, W43, W44 }\end{array}$ & 9 \\
\hline & (2) menyerang & W04, W15 & 2 \\
\hline & (3) melemahkan & $\begin{array}{l}\text { W05, W06, W08, W16, W17, W18, W25, } \\
\text { W27, W28, W45 }\end{array}$ & 10 \\
\hline & (4) mengejek atau merundung & W06, W16, W25, W37 & 4 \\
\hline & (4) menyalahkan & W20, W30,W31, W40, W41, W42, W43 & 7 \\
\hline & $\begin{array}{l}\text { (5) mengungkapan yang } \\
\text { sebaliknya }\end{array}$ & W38, W46. & 6 \\
\hline
\end{tabular}


JURNAL KIPRAH, Desember 2018; V1(2): 37-47

e-ISSN: 2580-6947

p-ISSN: 2354-7278

\begin{tabular}{|l|l|l|c|}
\hline & (6) melawan & $\begin{array}{l}\text { W04, W15, W23, W24 } \\
\text { W35, W36, W37, W43, W44 }\end{array}$ & 9 \\
\cline { 2 - 4 } & W30,W31, W40, W41, & 4 \\
\cline { 2 - 4 } $\begin{array}{l}\text { (8) mengecilkan/meremehkan } \\
\text { mengangkat diri. }\end{array}$ & $\begin{array}{l}\text { W04, W15, W23, W36, } \\
\text { W43, W44 }\end{array}$ & 6 \\
\hline
\end{tabular}

Berdasarkan data di atas, maka pada aspek konteks, wacana terbanyak berisi pernyataan (16 teks), tanggapan atas pernyataan (9 teks), dan yang paling sedikit adalah ulasan (1 teks). Pada aspek latar belakang, yang paling banyak menunjukkan identitas kekuasaan (12 teks) dan melemahkan kekuasaan (5 teks); sedangkan yang paling sedikit adalah mengungkapkan sejarah. Pada aspek sosial budaya, wacana terbanyak berisi mengkritik, melemahkan, dan melawan $(9,10$, dan 9 teks); sedangkan yang paling sedikit adalah menyerangkan (2 teks). Berdasarkan data tersebut dapat dibuat peta makna wacana berdasarkan analisis mikrostruktural dan makrostruktural tuturan sebagai berikut.

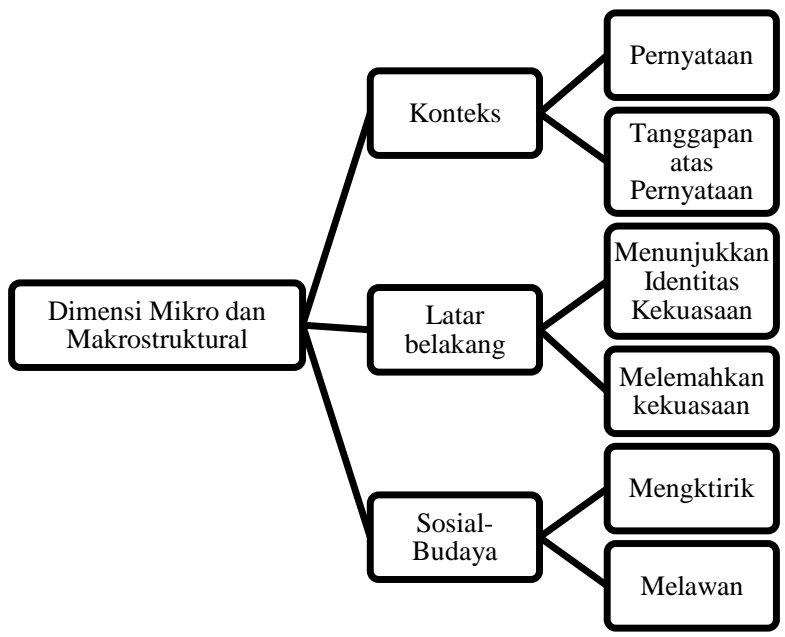

Bagan 1. Faktor Dimensi Mikro dan Makro Struktural Pada Wacana Politik Kelompok

Dari analisis data tersebut dapat disimpulkan bahwa bentuk lingual wacana politikus pada umumnya adalah kalimat deklaratif, yakni memberi pernyataan dan menanggapi pernyataan. Adapun latar belakang produksi wacana dari sudut pandang analisis wacana kritik adalah untuk tujuan menunjukkan identitas kekuasaan, melemahkan kekuasaan, mengkritik, dan melawan.

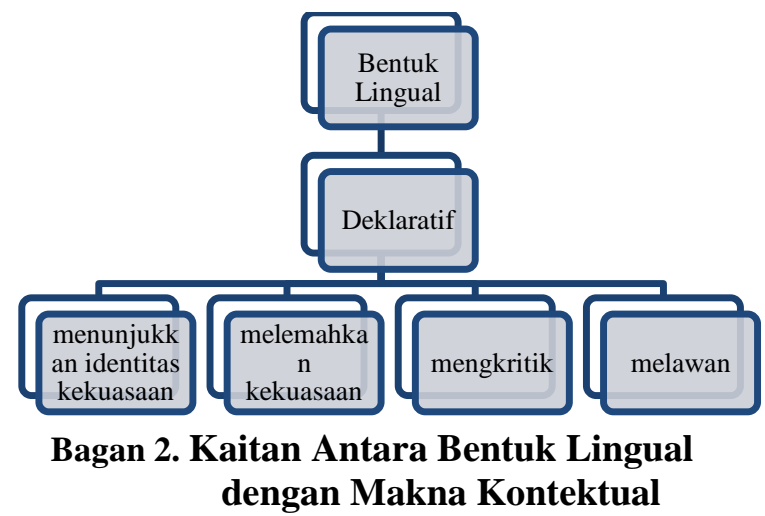

Hasil penelitian mendukung pandangan kaum post-strukturalisme, seperti Jurgen Habermas, Jean Baudrillard, Antonio Gramsci, Michel Foucault dan lain-lain menegaskan betapa pentingnya relasi antara bahasa dan kekuasaan. (Pentzold et al., 2016). Sama halnya dengan studi kesantunan berbahasa, menurut Brown \& Levinson (Brown \& Levinson, 1987), hubungan antara bahasa dan kekuasaan dikaji pada ranah apa yang baik dan apa yang buruk, atau apa yang santun dan apa yang kurang santun. Hal ini memang selayaknya, karena bahasa tidak dapat dipisahkan dari budaya. Bahasa adalah produk budaya, yang hidup dan berkembang pada dimensi kehidupan manusia. Implikasinya adalah bahwa kebudayaan suatu masyarakat tecermin pada nilai-nilai kebahasaan mereka. Nilai-nilai kebahasaan dapat berubah sesuai perkembangan kebudayaan, dan bahasa merupakan titik sentral berkembangnya suatu kebudayaan. Sekaitan dengan hal itu, maka penggunaan bahasa yang "amburadul" mengindikasikan lemahnya penghormatan dan penghargaan suatu bangsa terhadap budayanya.

Bahasa sebagai alat politik tecermin melalui retorika-retorika dan narasi-narasi yang dibangun oleh para elit politik pada ranah publik. Retorika menjadi lebih berefek dengan tambahan intonasi dan nada suara yang membius sehingga 
pendengarnya mau bertindak sesuai dengan isi pesan yang disampaikan. Politisi sangat menyadari kekuatan bahasa dalam mempengaruhi pikiran manusia. Mereka menganggap bahwa bahasa dapat dijadikan alat politik atau alat kontrol sosial. Dalam kaitan itu, hasil penelitian ini mendukung beberapa penelitian sebelumnya (Widiatmoko, n.d.), (Paulus, Warren, \& Lester, 2016), dan (Pentzold et al., 2016).

Bagi politisi, di satu sisi, bahasa dapat dijadikan alat untuk mencari simpati dan dukungan rakyat dan dapat juga dijadikan propaganda atau perang wacana para politisi. Bahasa digunakan untuk mencari simpati dan dukungan rakyat melalui penghalusan tuturan menggunakan majas eufemisme. Sisi ini adalah sisi positif yang masih perlu dipertahankan keberadaannya. Pada sisi ini penggunaan majas, masih pada jalur stilistika, yakni membungkus bahasa dengan pilihan kata tertentu agar timbul efek keindahan dan kebaikan, serta memunculkan simpati dari penerimanya.

Namun di sisi lain, temuan penelitian ini menunjukkan bahwa dewasa ini berkembang penggunaan majas yang jauh menyimpang dari stilistika. Bahasa telah digunakan untuk melancarkan propaganda dan perang wacana yang sarat kebencian, pembunuhan karakter, penelanjangan kejelekan orang lain, pembohongan publik, dan sebagainya. Eufemisme telah dilupakan dan diganti dengan sarkasme. Unsur keindahan sebagai tujuan awal penggunaan gaya bahasa untuk menarik simpati menjadi hilang sama sekali, berganti dengan unsur kekerasan, kebencian, permusuhan, dan lain-lain yang menimbulkan antipati. Fungsi dan bentuknya telah menyimpang dari konsepsi umum penggunaan gaya bahasa sebagai pelanyah interaksi agar muncul sikap empati.

Hasil penelitian menunjukkan bahwa ada 4 kelompok dan 36 jenis gaya bahasa (majas) yang digunakan oleh para politikus dalam bertutur di media sosial daring, yaitu majas sindiran (21 jenis), perbandingan (7 jenis), pertentangan (4 jenis), dan penegasan (4 jenis). Dari ketiga puluh enam jenis majas tersebut, majas yang paling sering digunakan adalah anakronisme dan kontradiksio in terminis (majas pertentangan), serta sarkasme, sinisme, dan ironi (majas sindiran). Dengan demikian wacana yang muncul dalam tuturan politisi adalah pertentangan dan sindiran, yang keduanya tergolong pada anomali penggunaan bahasa sebagai alat komunikasi, interaksi, dan menjaga hubungan baik, yang merupakan fungsi bahasa dalam ranah sosial. Penggunaan majas sarkasme berkaitan erat dengan berubahnya budaya masyarakat Indonesia, dari budaya tradisional yang lebih menekankan pada tata krama, subha sita, unggah-ungguh, tepo sliro dalam berinteraksi, menjadi budaya global yang lebih artifisial, kebendaan, hedonis, dan hal-hal yang bersifat duniawiah. Bahasa sarkasme adalah bahasa kasar digunakan untuk menyakiti hati orang lain atau pendengarnya. Eufemisme atau penghalusan bahasa telah jauh berkurang dalam wacana politik masa kini, khususnya di Indonesia.

Eufemisme merupakan acuan bagi tuturan yang tidak menyinggung perasaan atau ungkapan halus untuk menggantikan acuan yang dirasakan menghina atau tidak menyenangkan. Intinya, mempergunakan kata-kata dengan arti baik. Eufemisme juga sering diartikan sebagai ungkapan yang bersifat tidak berterus terang. Eufemisme atau juga pseudo eufemisme menjadi motif dorongan di belakang perkembangan peyorasi. Eufemisme berlatar belakang sikap manusiawi karena dia berusaha untuk menghindar agar tidak menyakiti atau menyinggung perasaan orang.

Contoh konkret adalah penggunaan kata "muka" pada frase berikut:

1) muka Boyolali [data P-05/W10].

Apa pun konteks tuturnya, penggunaan kata "muka" yang diikuti oleh [nama], cenderung bermakna negatif, seperti "muka setan, muka kucing, muka singa, muka memar, muka pucat, muka Cina, muka tembem, dsb". Meskipun ada juga kata "muka manis, muka cantik, muka ganteng, muka kaya, dsb", tetapi penggunaan kata "muka" pada "muka manis, muka cantik, muka ganteng, muka kaya" tidaklah cocok. Akan berbeda maknanya jika kata "muka" pada "muka 
JURNAL KIPRAH, Desember 2018; V1(2): 37-47

e-ISSN: 2580-6947

p-ISSN: 2354-7278

manis, muka cantik, muka ganteng, muka kaya" diganti dengan "wajah", sehingga frase tersebut berbunyi "wajah manis, wajah cantik, wajah ganteng, wajah kaya, dsb". Jadi penggunaan eufemisme kata "muka" menjadi "wajah" akan memberikan efek makna yang berbeda pada diri penerima.

Analog dengan contoh tersebut adalah penggunaan kata "rai" dalam Bahasa Jawa yang juga berarti "muka". Kata "rai" bermakna kurang sopan, seperti pada contoh "raimu" (wajahmu), "raine" (wajahnya), "rai gedeg" (tidak tahu malu), "rai upa" (sering ingin makan), dsb. Orang Jawa menghindari kata "rai" jika berbicara. Mereka mengubahnya dengan menggunakan eufemisme dengan meningkatkan level kesantunannya. Kata "rai" (bahasa ngoko) diubah menjadi "pasuryan" (bahasa krama), keduanya berarti wajah. Mungkin juga, tidak menggunakannya sama sekali kata tersebut. Misalnya, frasa "wajahnya cantik sekali" tidak dikatakan "raine ayu banget", tetapi kata "raine" dibuang, dan hanya disebutkan "ayu banget" (cantik sekali).

Majas anakronisme termasuk dalam salah satu majas pertentangan. Kata anakronisme ini terbagi dengan 2 kata, ana yang berarti mundur dan chromos berarti waktu. Jadi majas ini digunakan untuk menceritakan sesuatu yang telah terjadi yang bernilai masa lalu atau sejarah. Sehingga kita simpulkan majas anakronisme adalah majas yang menunjukkan gaya bahasa yang berupa pengungkapan atau sesuatu yang mengandung ketidaksesuaian dengan waktu dan peristiwa yang dibicarakan saat itu.

Dalam konteks wacana politik, majas anakronisme digunakan untuk mempertentangkan sesuatu di masa lalu, namun tujuannya bukan lagi untuk melayahkan tuturan dan membuat efek keindahan, tetapi sebaliknya untuk mengejek atau merundung lawan politiknya. Jadi, makna pertentangan digunakan dengan menjungkirbalikkan fakta sebenarnya dengan maksud menggiring pembaca untuk antipati dan tidak memercayai lagi lawan politiknya. Contoh pada teks berikut:

2) rakyat Indonesia 99 persen hidup paspasan, lebih enak jaman dulu [P04/W01]

3) harga-harga bahan pokok di pasar naik, tempe setipis ATM [P04/W06]

4) chicken rice di Singapura lebih murah dibandingkan di Jakarta [P04/W31]

Ketiga contoh tersebut adalah penggunaan majas anakronisme tetapi mengandung makna ironi. Ketiga kalimat tersebut ingin mengandung struktur makna kontekstual sebagai berikut:

pemerintah tidak sanggup membuat rakyat sejahtera --> pemerintah telah gagal membangun ekonomi --> pemerintah harus diganti.

Jadi, ketiga contoh tersebut saling berkaitan meskipun disampaikan pada konteks, waktu, tempat, dan audiens yang berbeda. Makna kontekstual dari sudut pandang makrostruktural adalah:

\section{presiden tidak berkompeten \\ presiden harus diganti \\ anda harus memilih saya sebagai penggantinya.}

Dengan demikian, kalimat "Rakyat Indonesia 99 persen hidup pas-pasan," dari segi struktur bukan kalimat berita tetapi kalimat pernyataan, dari segi latar belakang bertujuan untuk melemahkan kekuasaan dan menunjukkan identitas kekuasaan, dan dari segi sosial-budaya bermakna mengkritik, menyerang, melemahkan, mengejek, menyalahkan, dan mengecilkan/ meremehkan.

Majas kontradiksi interminus adalah majas yang menggunakan pernyataan yang bersifat menyangkal yang telah disebutkan pada bagian sebelumnya. Maka dari itu, majas ini termasuk dalam kategori majas pertentangan. Contohnya pada teks berikut.

5) Sepertinya di rezim orde baru itu mengambil hak rakyat yang bernama subisidi bahan bakar itu hati-hati sekali dan diselenggarakan dengan baik, supaya masyarakat tahu kenapa dilakukan ini [P02/W05] 
Pada wacana tersebut penutur mempertentangkan kebijakan dua rezim, yakni rezim orde baru (era Suharto) dan rezim sekarang (era Jokowi). Akan tetapi, wacana pertentangan tidak disampaikan seluruhnya. Ada kalimat yang dihilangkan. Wacana lengkap mestinya:

6) Sepertinya di rezim orde baru itu mengambil hak rakyat yang bernama subisidi bahan bakar itu hati-hati sekali dan diselenggarakan dengan baik, supaya masyarakat tahu kenapa dilakukan ini. $\underline{\text { Di }}$ rezim sekarang mengambil hak rakyat yang bernama subsidi bahan bakar tidak hati-hati dan tidak diselenggarakan dengan baik.

Bagian kedua dari wacana [P02/W05] adalah interpretasi kontekstual dari bagian pertama. Dasarnya adalah wacana tersebut disampaikan untuk mengkritik pemerintah, maka maksud kalimat bagian kedua adalah kebalikan (pertentangan) dari maksud kalimat bagian pertama. Anomali penggunaan majas kontradiksi interminus terjadi dalam wacana politik karena pertentangan bukan berarti maksud wacana bagian pertama dipertentangkan dengan maksud bagian kedua, misalnya pada kalimat "Ia makan, tetapi masih lapar". Interpretasi majas pada wacana politik tidak sesederhana itu.

Gaya bahasa sarkasme, sinisme, dan ironi yang tergolong majas sindiran menempati porsi terbanyak dari seluruh data yang terkumpul. Bahkan, dapat dikatakan bahwa hampir keseluruhan majas yang digunakan dalam wacana politik, termasuk anakronisme dan kontradiksio in terminis (majas pertentangan) bermakna sindirian (ironi). Namun di antara kelompok majas yang digunakan elit politik , terdapat penggunaan majas sarkasme dan sinisme yang cukup sering. Artinya, retorika dan narasi politik tidak lagi memedulikan penghalusan bahasa untuk kepentingan kesantunan. Gejala ini patut menjadi pemikiran bersama.

Berdasarkan data yang terkumpul, dari 48 teks, 21 teks berisi tuturan dengan gaya bahasa ironi (sarkasme, sinisme, dan ironi). Sisanya berupa gaya bahasa perbandingan (7 jenis), pertentangan (4 jenis), dan penegasan (4 jenis). Namun demikian, gaya bahasa perbandingan dan pertentangan yang digunakan dalam bertutur, sebagian juga bermakna ironi. Hal ini berarti kurang lebih separoh wacana mengandung majas ironi yang tergolong pada penggunaan bahasa tidak santun.

Analisis data menunjukkan adanya model baru wacana, yaitu wacana politik. Model wacana politik merupakan "irisan" antara fungsi bahasa sebagai alat interaksi dan menjaga hubungan baik (fungsi pragmatik), fungsi bahasa sebagai alat kekuasaan (fungsi politik), dan fungsi bahasa sebagai alat untuk mendeseminasikan keyakinan (fungsi ideologis).

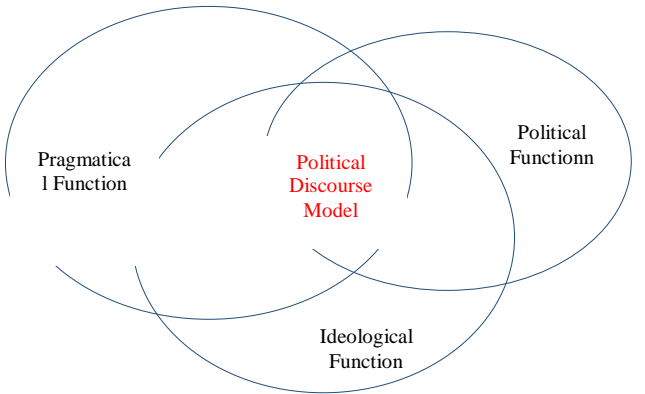

\section{Bagan 3. Model Wacana Politik}

Dari analisis diketahui 4 fenomena menarik ragam bahasa politikus oposan di Indonesia, yaitu, (1) kecenderungan untuk menggunakan diksi yang bermakna sarkastik, melecehkan, membuli, menyudutkan, menyatakan yang sebaliknya, dan apriori; (2) kebenaran realistis dikalahkan oleh kebenaran praktis, (3) hilangnya sikap empati, penghargaan, dan kesantunan; (4) bahasa digunakan sebagai alat politik, dan bukan sebagai alat interaksi sebagaimana dimaksud dalam teori kesantunan berbahasa. Penggunaan bahasa tersebut menunjukkan kecenderungan munculnya ideologi neo-imperialisme dan prodisintegrasi yang dapat berdampak luas pada stabilitas sosial, politik, dan keamanan bangsa dan negara. Inilah penciri utama model baru wacana, yakni wacana politik khas Indonesia, yang berbeda dengan wacana wacana politik di luar negeri, seperti yang dikemukakan oleh Gergen (Gergen, 2012) 
JURNAL KIPRAH, Desember 2018; V1(2): 37-47

e-ISSN: 2580-6947

p-ISSN: 2354-7278

\section{Kesimpulan}

Hasil penelitian menunjukkan adanya kaitan yang erat antara bahasa dan politik, bahasa dan kekuasaan. Praktik penggunaan bahasa dalam wacana politik dilatarbelakangi oleh ideologi dan filosofis khas. Pada wacana politik di Indonesia, latar belakang ideologis dan filosofis tersebut tampak nyata dalam penggunaan gaya bahasa yang dapat diamati pada pilihan kata, struktur kalimat, makna pragmatik, dan tujuan berwacana.

Penelitian juga telah menghasilkan rumusan model wacana khas politik di Indonesia. Model tersebut merupakan interelasi (irisan) antara fungsi bahasa sebagai alat interaksi dan menjaga hubungan baik (fungsi pragmatik), fungsi bahasa sebagai alat kekuasaan (fungsi politik), dan fungsi bahasa sebagai alat untuk mendeseminasikan keyakinan (fungsi ideologis). Model wacana politik khas Indonesia tersebut dicirikan oleh, (1) kecenderungan untuk menggunakan diksi yang bermakna sarkastik, melecehkan, membuli, menyudutkan, menyatakan yang sebaliknya, dan apriori; (2) kebenaran realistis dikalahkan oleh kebenaran praktis, (3) hilangnya sikap empati, penghargaan, dan kesantunan; (4) bahasa digunakan sebagai alat politik, dan bukan sebagai alat interaksi sebagaimana dimaksud dalam teori kesantunan berbahasa.

\section{Daftar Pustaka}

Brown, P., \& Levinson, S. (1987). Politeness: Some Universals in Language Use. Studies in Interactional Sociolinguistics 4. https://doi.org/10.2307/3587263

Dafrizal, J. (2016). Teori belajar behaviorisme dan implikasinya dalam praktek pendidikan, (December 2015), 0-61.

de Beaugrande, R. (2006). Critical discourse analysis: History, ideology, methodology. Studies in Language and Capitalism, 1(Beaugrande), 29-56. https://doi.org/diskursanalyse; qualitative methode; ideologie

Fairclough, N. (1995). Critical Discourse Analysis. London: Longman Group
Limited. https://doi.org/10.2307/329335

Fairclough, N. (2001). Critical discourse analysis (Vol.

https://doi.org/10.4135/9781849208871

Gergen, K. (2012). Social Constructionism. https://doi.org/1000-1005. 10.1007/978-14419-0463-8_71.

Kuntarto, E. (1999). Strategi Kesantunan Dwibahasawan Indonesia-Jawa Kajian Pada Wacana Lisan Bahasa Indonesia. Disertasi IKIP Malang. Repository Universitas Jambi. Retrieved from www.repository.unja.ac.id

Kuntarto E. (2017). Telaah Linguistik untuk Guru Bahasa. Repository Universitas Jambi. Retrieved from www.repository.unja.ac.id

Kuntarto E. (2018). Prosiding Seminar Nasional Aprobsi. Repository Unja. Retrieved from www.repository.unja.ac.id

Levinson, S. (1983). Pragmatics. Pragmatics. Cambridge University Press. doi:10.1017/CBO9780511813313.002. https://doi.org/10.1017/CBO978051181331 3.002

Nasution, Z. (2007). Bahasa Sebagai Alat Komunikasi, 01(03), 445-464.

Paulus, T., Warren, A., \& Lester, J. N. (2016). Applying conversation analysis methods to online talk: A literature review. Discourse, Context \& Media, I2(June 2016), 1-10. https://doi.org/https://doi.org/10.1016/j.dc m.2016.04.001

Pentzold, C., Sommer, V., Meier, S., \& Fraas, C. (2016). Reconstructing Media Frames in Multimodal Discourse: The John/Ivan Demjanjuk Trial. Discourse, Context \& Media, 12(June 2016), 32-39. https://doi.org/10.1016/j.dcm.2016.03.001

Redinger, D. (2010). Language Attitudes and Code-switching Behaviour in a Multilingual Educational Context: The Case of Luxembourg. PhD Thesis, (August), 408. https://doi.org/http://dx.doi.org/10.1016/j.r obot.2015.04.001

Weiss, G and Wodak, R. (2006). Critical 
Kuntarto: Bahasa dan Kekuasaan Politik ... (7)

Discourse Analysis. (Gilbert Weiss and Ruth Wodak, Ed.), Encyclopedia of Language \& Linguistics. Palgrave Macmillian. https://doi.org/10.1016/B0-08$\underline{044854-2 / 00501-0}$

Widiatmoko, B. (n.d.). Analisis bahasa politik pejabat publik indonesia berdasarkan tinjauan filsafat nilai, 48-49. 